\title{
INKORPORASI TEPUNG GARUT DAN BUAH PISANG KEPOK PADA PEMBUATAN BISKUIT DENGAN KLAIM TINGGI SERAT SERTA TINJAUAN NILAI CERNA PATI IN VITRO DAN GULA TOTAL
}

\author{
Nurul Azizah Choiriyah ${ }^{1}$ \\ ${ }^{1}$ Akademi Kuliner dan Patiseri OTTIMMO Internasional \\ Jalan Citraland Surabaya No. 3 Kec Sambikerep, Surabaya, Jawa Timur 60217 \\ Email : nurul.azizah.choiriyah@gmail.com
}

\section{Article Info \\ Article history: \\ Received July $14^{\text {th }}, 2020$ \\ Revised August $21^{\text {th }}, 2020$ \\ Accepte September $25^{\text {th }}, 2020$}

\section{Keyword:}

Arrowroot flou; Biscuit; Fiber; Kepok banana; Starch digestibility

\section{Kata Kunci :}

Biskuit; Nilai cerna pati; Serat; Tepung garut; Pisang kepok

\begin{abstract}
Objectives : The purpose of this study was to evaluate biscuit formulations from arrowroot flour and kepok banana for making high dietary biscuits according to BPOM regulation about high dietary fiber claim, also to study about starch digestibility and total sugar content of the biscuits.
\end{abstract}

Methods : Variables of this study was F1 (the ratio of arrowroot flour : kepok banana $=50: 125 \mathrm{~g}$ ), F2 (the ratio of arrowroot flour : kepok banana $=75: 100 \mathrm{~g}$ ) and F3 (the ratio of arrowroot flour : kepok banana $=100: 75 \mathrm{~g}$ ).

Results : The results of this study were the F3 biscuits have the highest dietary fiber (15\%). All biscuits fulfill the high dietary fiber claim according to BPOM regulations. Invitro starch digestibilitiy of F1, F2 and F3 biscuits were 35,07\%, 33,15\% and 34,80\%, respectively. Total sugar content of F1, F2 and F3 biscuits were $34,27 \%, 32,45 \%$ and $26,85 \%$, respectively. F3 biscuits have the lowest total sugar content.

\begin{abstract}
ABSTRAK
Tujuan : Penelitian ini bertujuan untuk mengevaluasi formula biskuit menggunakan tepung garut dan buah pisang dengan berbagai konsentrasi untuk menghasilkan biskuit tinggi serat sesuai persyaratan BPOM, serta mengkaji nilai cerna pati dan kadar gula total produk biskuit.
\end{abstract}

Metode : Perlakuan dalam penelitian ini yaitu F1 (perbandingan tepung garut:buah pisang = 50:125 gram), F2 (perbandingan tepung garut:buah pisang $=75: 100$ gram) dan $F 3$ (perbandingan tepung garut: buah pisang $=100: 75$ gram).

Hasil : Hasil penelitian ini yaitu biskuit F3 memiliki kadar serat pangan paling tinggi yaitu 15\%. Ketiga biskuit memenuhi syarat klaim tinggi serat sesuai peraturan BPOM. Nilai cerna pati in vitro biskuit F1, F2 dan F3 masing-masing 35,07 \%, 33,15\% dan 34,80 \%. Kadar gula total biskuit F1, F2 dan F3 masing-masing 34,27 \%, $32,45 \%$ dan 26,85\%. Biskuit F3 memiliki kadar gula total paling rendah.

Copyright () Jurnal Gizi Prima All rights reserved.

\section{PENDAHULUAN}

Seiring dengan perkembangan gaya hidup yang tidak sehat dan konsumsi makanan yang tidak sehat maka 
orang yang menderita penyakit diabetes sangat tinggi di berbagai belahan dunia. CDC melaporkan bahwa 34,2 juta penduduk Amerika atau sekitar 1 dari 10 orang Amerika menderita diabetes. Orang yang menderita diabtes diantaranya $10 \%$ perokok, $89 \%$ obesitas dan $38 \%$ merupakan orang yang jarang melakukan aktivitas fisik (CDC, 2020). Data WHO (2020) menunjukkan bahwa, orang yang menderita diabetes terus meningkat, yaitu empat ratus dua puluh juta orang di tahun 2014 dari semula sejumlah serratus delapan juta orang di tahun 1980. Prevalensi diabetes meningkat dengan lebih cepat pada negara dengan pendapatan rendah dan menengah daripada negara dengan pendapatan tinggi. Pada tahun 2016, sekitar 1,6 juta orang meninggal dunia karena diabetes. Jenis diabetes mayoritas adalah diabetes tipe 2 yang dihasilkan oleh penggunaan insulin yang tidak efektif oleh tubuh.

Makanan sehat seperti makanan tinggi serat pangan dapat mencegah penyakit diabetes tipe 2 . Konsumsi serat secara konsisten yaitu sekitar 30-50 g per hari dapat menurunkan kadar glukosa darah. Serat memiliki efek positif terhadap sensitivitas insulin pada orang dengan diabetes tipe 2, menaikkan kadar HDL (High Density Lipoprotein) dengan penurunan kolesterol yang buruk bagi tubuh (Erukainure et al., 2013).

Serat pangan merupakan komponen tanaman yang tidak tercerna oleh usus halus manusia. Serat pangan mengakibatkan efek kenyang, memperlambat waktu kosong lambung, memperlambat absorpsi nutrient (Patel, 2015). Menurut Peraturan BPOM No 13 tahun 2016, suatu produk dapat diklaim sebagai tinggi serat apabila memiliki kandungan serat 6 g per 100 gram (BPOM, 2016).

Biskuit disukai berbagai kalangan karena harganya relatif murah. Biskuit juga disukai karena praktis, bernilai gizi tinggi dan memiliki bentuk serta ukurannya beragam. Biskuit biasanya terbuat dari tepung terigu. Sebagian besar formulasinya biasanya mengandung tinggi karbohidrat dan rendah serat. Untuk meningkatkan kesadaran terhadap perilaku gaya hidup sehat, telah banyak peneliti yang mengkaji produksi biskuit yang mengandung serat pangan (Bolek, 2020). Cepo and Dragojevi (2014) menggunakan $30 \%$ tepung gandum utuh, tepung oat, tepung amaranth untuk menggantikan tepung terigu yang dapat menghasilkan biskuit tinggi serat sehingga menyebabkan penurunan beban glikemik. Delamare et al. (2020) menggunakan penggantian tepung terigu dengan bahan legume (PulseON®) sebesar $50 \%$ untuk membuat biskuit tinggi serat.

Umbi garut merupakan bahan baku lokal yang mudah ditemukan di Indonesia. Umbi garut merupakan bahan sumber karbohidrat. Umbi garut telah banyak diolah dan dipasarkan sebagai tepung garut. Tepung garut berpotensi dikembangkan sebagai makanan prebiotik (Harmayani et al., 2011). Penelitian Lestari et al. (2020) menunjukkan bahwa pati garut berpotensi sebagai diet khusus untuk mencegah obesitas dan diabetes karena nilai cerna patinya rendah dan kandungan serat yang tinggi. Tepung garut memiliki rasa hambar sehingga cocok digunakan untuk bahan pengganti tepung terigu (Dyah and Eni, 2012).

Buah pisang merupakan pangan yang mengandung tinggi serat (Sondak et al., 2018). Buah pisang kepok memiliki rasa manis sehingga penambahan buah pisang dapat memperbaiki rasa biskuit berbahan dasar tepung garut. Buah pisang kepok merupakan buah yang yang ketersediaannya melimpah dan memiliki umur simpan pendek. Pengolahan pisang menjadi biskuit dapat meningkatkan nilai ekonomi komoditas tersebut. Belum pernah ada penelitian mengenai pembuatan biskuit dengan menggunakan tepung garut yang dikombinasikan pada buah pisang. Penggunaan tepung garut dan buah pisang diharapkan mampu menghasilkan biskuit tinggi serat dengan nilai cerna pati rendah yang bermanfaat bagi penderita diabetes. Sehingga pada penelitian ini bertujuan untuk mengevaluasi formula biskuit menggunakan tepung garut dan buah pisang dengan berbagai konsentrasi untuk menghasilkan biskuit tinggi serat sesuai persyaratan BPOM, serta mengkaji nilai cerna pati in vitro dan kadar gula total produk biskuit yang dihasilkan.

\section{METODE PENELITIAN}

\section{Bahan dan Alat}

Bahan-bahan untuk persiapan biskuit diantaranya: tepung terigu "Cakra Kembar", tepung garut merk "IELS Organic", buah pisang kepok, margarin, gula dan garam. Bahan yang digunakan untuk analisis yaitu larutan buffer phospat $0,1 \mathrm{M} \mathrm{pH} \mathrm{7,} \mathrm{enzim} \mathrm{alpha} \mathrm{amilase,} \mathrm{enzim} \mathrm{pepsin} \mathrm{1 \% ,} \mathrm{enzim} \mathrm{beta} \mathrm{amilase,} \mathrm{ethanol} 95 \%$, aseton, aquadest, HCL 25\%, $\mathrm{NaOH} 45 \%$, reagen nelson C, Arseno Molibdat, D-Glukose.

Alat yang digunakan dalam pembuatan biskuit yaitu baskom plastik, mixer, rolling pin, sendok, sarung tangan plastik, telenan besar, chopper, oven, nampan. Alat yang digunakan untuk analisis diantaranya 
Erlenmeyer, aluminium foil, penangas air, kertas saring, oven memmert, desikator, inkubator, waterbath, Vortex, spektrofotometer, tabung reaksi, penyangga tabung reaksi.

\section{Metode Penelitian}

Metode penelitian menggunakan Rancangan Acak Lengkap yang terdiri dari 3 perlakuan dengan perlakuan masing-masing dilakukan 2 ulangan dan analisis dilakukan 3 kali ulangan. Perlakuan yang digunakan yaitu perbandingan tepung garut dan buah pisang terdiri dari sampel F1 (perbandingan tepung garut:buah pisang = 50:125 gram), sampel F2 (perbandingan tepung garut:buah pisang = 75:100 gram), sampel F3 (perbandingan tepung garut:buah pisang $=100: 75$ gram). Data dianalisis statistik dengan ANOVA dan analisis lanjutan DMRT pada taraf $5 \%$.

\section{Prosedur Penelitian \\ Proses Pembuatan Biskit}

Proses pembuatan biskuit mengacu pada metode Erukainure et al. (2013) yang dimodifikasi. Proses pembuatan biskuit sebagai berikut: bahan tambahan seperti margarin $(62,5 \mathrm{~g})$, gula (80 g) dan garam (1 g) dicampur dengan mixer selama 20 menit. Buah pisang dengan perlakuan $(125,100,75 \mathrm{~g})$ dihaluskan menggunakan chopper hingga terbentuk puree pisang. Selanjutnya, puree pisang dicampur dengan campuran margarin, gula dan garam. Selanjutnya ditambahkan tepung terigu dan tepung garut sesuai perlakuan $(50,75$, $100 \mathrm{~g}$ ), kemudian dicampur hingga menjadi adonan yang kalis. Adonan selanjutnya dicetak menggunakan rolling pin dengan ukuran $5 \times 4 \times 0,5 \mathrm{~cm}$. Pengovenan dilakukan pada suhu $180 \mathrm{oC}$ selama 30 menit.

\section{Pengamatan}

Analisis dilakukan pada produk biskuit. Analisis yang dilakukan yaitu analisis serat pangan dan nilai cerna pati in vitro menggunakan metode AOAC (2012). Analisis gula total menggunakan metode Nelson-Somogy (Sudarmadji, 2006) (Sehgal et al., 2017)(Baranski et al., 2012).

\section{HASIL DAN PEMBAHASAN}

Hasil uji laboratorium untuk kadar serat pangan dan nilai cerna pati disajikan pada Tabel 1.

Tabel 1. Data Analisis serat Pangan, Nilai Cerna Pati In Vitro dan Gula Total

\begin{tabular}{|c|c|c|c|}
\hline \multirow[b]{2}{*}{ Analisis } & \multicolumn{3}{|c|}{ Perlakuan } \\
\hline & F1 & F2 & F3 \\
\hline Serat pangan $(\%)$ & $9,30 \mathrm{a}$ & $12,67 \mathrm{~b}$ & $15 \mathrm{c}$ \\
\hline Nilai cerna pati in vitro $(\%)$ & $35,07 \mathrm{a}$ & $33,15 a$ & $34,80 \mathrm{a}$ \\
\hline Total Gula (\%) & $34,27 b$ & $32,45 b$ & $26,85 \mathrm{a}$ \\
\hline
\end{tabular}

\section{Serat Pangan}

Menurut Peraturan BPOM No 13 tahun 2016, suatu produk dapat diklaim sebagai tinggi serat apabila memiliki kandungan serat 6 g per 100 gram atau sebesar $6 \%$. Pada penelitian ini, produk biskuit yang dihasilkan memiliki kadar serat pangan sebesar 9,30-15\%. Hal ini berarti bahwa biskuit yang dihasilkan semuanya memenuhi persyaratan BPOM untuk diajukan sebagai makanan dengan klaim tinggi serat.

Sampel F3 yang dibuat dengan menggunakan perbandingan tepung garut:buah pisang = 100:75 gram memiliki kadar serat pangan paling tinggi disusul dengan sampel F2 yang dibuat dengan menggunakan perbandingan tepung garut:buah pisang $=75: 100$ gram dan kadar serat paling rendah pada sampel F1 yang dibuat dengan menggunakan perbandingan tepung garut:buah pisang $=50: 125$ gram. Hal ini berarti bahwa semakin tinggi penggunaan tepung garut yang diiringi dengan penurunan penggunaan buah pisang kepok dapat meningkatkan kadar serat pangan. Menurut Harmayani et al. (2011) tepung garut mengandung tinggi serat pangan sebesar 16,84 \% sedangkan Data Komposisi Pangan Indonesia (2020) buah pisang mengandung serat pangan sebesar $5,7 \%$.

\section{Nilai Cerna Pati In Vitro}

Nilai cerna pati in vitro merupakan kemampuan enzim alpha amilase dalam memecah pati menjadi gula-gula sederhana (glukosa). Jumlah glukosa diukur dengan metode spektrofotometri setelah direaksikan dengan asam dinitrosalisilat (DNS) dan diinkubasi selama 2,5 jam. Nilai cerna pati in vitro dihitung sebagai persentase terhadap pati murni (Maulani and Hidayat, 2016). 
Nilai cerna pati in vitro pada produk biskuit sekitar 33,15-35,07\%. Ketiga sampel biskuit tidak memiliki perbedaan yang signifikan pada nilai cerna pati in vitro. Nilai cerna pati in vitro produk biskuit ini tergolong rendah jika dibandingkan dengan penelitian (Li et al., 2020). Li et al. (2020) meneliti nilai cerna pati invitro pada cookies yang dibuat dari ekstrak kacang kedelai, hasilnya menunjukkan sampel tersebut memiliki nilai cerna pati in vitro setelah inkubasi sampel 2,5 jam sekitar $60 \%$.

Nilai cerna pati dipengaruhi oleh kadar serat pangan terlarut. Serat pangan terlarut dapat meningkatkan viskositas gel sehingga dapat menurunkan absorpsi pada usus halus (Li et al., 2020). Berdasarkan penelitian Claudia and Wijanarko (2016) rendahnya nilai cerna pati in vitro juga berhubungan dengan tingginya kadar amilosa bahan. Tepung garut memiliki kadar amilosa yang tinggi yaitu sebesar 29,4 \% (Aprianita et al., 2014). Semakin rendah nilai cerna pati in vitro maka semakin sedikit glukosa yang dihasilkan dari proses hidrolisis. Nilai cerna pati in vitro yang rendah berpotensi sebagai prebiotik (Harmayani et al., 2011).

\section{Gula Total}

Gula total yaitu semua gula dari suatu bahan pangan yang terdiri atas gula pereduksi juga gula non pereduksi, dan karbohidrat-karbohidrat berasal dari polisakarida, oligosakarida disakarida dan monosakarida. Penentuan gula total biskuit dilakukan menggunakan metode Nelson-Somogyi dimana sampel direaksikan dengan kalium ferisianida dan zink sulfat (Baranski et al., 2012). Gula total biskuit pada penelitian ini sekitar 26,85-34,37 \%. Sampel F3 yang dibuat dengan menggunakan perbandingan tepung garut:buah pisang = 100:75 gram memiliki kadar gula total paling rendah yaitu 26,85\%. Semakin tinggi penambahan tepung garut menyebabkan produk biskuit memiliki kadar gula total yang tinggi, hal ini dikarenakan tingginya kadar kabohidrat yang dimiliki tepung garut. Tepung garut memiliki kadar karbohidrat sekitar $82 \%$ (Aparecida et al., 2019) sedangkan buah pisang kepok hanya memiliki kadar karbohidrat sebesar $26 \%$ (Data Komposisi Pangan Indonesia, 2020)

\section{KESIMPULAN}

Biskuit yang dibuat dengan menggunakan perbandingan tepung garut:buah pisang = 100:75 gram memiliki kadar serat pangan paling tinggi yaitu 15\%. Hal ini berarti bahwa semakin tinggi penggunaan tepung garut yang diiringi dengan penurunan penggunaan buah pisang kepok dapat meningkatkan kadar serat pangan. Ketiga biskuit memenuhi syarat klaim tinggi serat sesuai peraturan BPOM. Nilai cerna pati in vitro biskuit F1, F2 dan F3 masing-masing 35,07 \%, 33,15 \% dan 34,80 \%. Kadar gula total biskuit F1, F2 dan F3 masingmasing 34,27 \%, 32,45 \% dan 26,85\%. Biskuit yang dibuat dengan menggunakan perbandingan tepung garut:buah pisang $=100: 75$ gram memiliki kadar gula total paling rendah. Semakin tinggi penambahan tepung garut menyebabkan produk biskuit memiliki kadar gula total yang tinggi, hal ini dikarenakan tingginya kadar kabohidrat yang dimiliki tepung garut.

\section{DAFTAR PUSTAKA}

Aparecida, J., Bento, C. and Carvalho, K. (2019) Physicochemical and technological characteristics of arrowroot flour modified by ultrasound and low-temperature heat treatment.

Aprianita, A., Vasiljevic, T., Bannikova, A. and Kasapis, S. (2014) Physicochemical properties of flours and starches derived from traditional Indonesian tubers and roots, 51 (December), pp. 3669-3679. DOI:10.1007/s13197-012-0915-5.

Baranski, R., Allender, C. and Klimek-chodacka, M. (2012) Towards better tasting and more nutritious carrots : Carotenoid and sugar content variation in carrot genetic resources, FRIN, 47 (2), pp. 182-187. DOI:10.1016/j.foodres.2011.05.006.

Bolek, S. (2020) Olive stone powder: A potential source of fiber and antioxidant and its effect on the rheological characteristics of biscuit dough and quality, Innovative Food Science and Emerging Technologies. DOI:10.1016/j.ifset.2020.102423.

BPOM (2016) Pengawasan Klaim Pada Label dan Iklan Pangan Olahan. Available from: https://www.pom.go.id/new/view/more/berita/12148/Pengawasan-Klaim.html [Accessed 27 May 2020].

CDC (2020) National Diabetes Statistics Report, 2020 CDC. Available from: https://www.cdc.gov/diabetes/library/features/diabetes-stat-report.html [Accessed 27 May 2020]. 
Cepo, D. V. and Dragojevi, I. V. (2014) LWT - Food Science and Technology Impact of dietetic tea biscuit formulation on starch digestibility and selected nutritional and sensory characteristics, pp. 1-7. DOI:10.1016/j.lwt.2014.06.003.

Claudia, E. J., Widjanarko, S. B., Teknologi, J., Pertanian, H., Universitas, F. T. P. and Malang, B. (2016) STUDI DAYA CERNA ( IN VITRO ) BISKUIT TEPUNG UBI JALAR KUNING DAN TEPUNG JAGUNG GERMINASI Study of In Vitro Digestibility in Biscuit Made From Yellow Fleshed Sweet Potato Flour and Germinated Maize Flour, 4 (1), pp. 391-399.

Data Komposisi Pangan Indonesia (2020) Data Komposisi Pangan Indonesia - Beranda. Available from: http://panganku.org/id-ID/view [Accessed 27 May 2020].

Delamare, G. Y. F., Butterworth, P. J., Ellis, P. R., Hill, S., Warren, F. J. and Edwards, C. H. (2020) Incorporation of a novel leguminous ingredient into savoury biscuits reduces their starch digestibility: Implications for lowering the Glycaemic Index of cereal products, Food Chemistry: X, 5 (August 2019), pp. 100078. DOI:10.1016/j.fochx.2020.100078.

Dyah, I. and Eni, K. (2012) Evaluation of immunostimulatory effect of the arrowroot ( Maranta arundinacea . L ) in vitro and in vivo, pp. 131-137. DOI:10.1007/s10616-011-9403-4.

Erukainure, O. L., Ebuehi, O. A. T., Adeboyejo, F. O., Okafor, E. N., Muhammad, A. and Elemo, G. N. (2013) improves insulin sensitivity, and attenuates hyperlipidemia in diabetic rats, Biochemical Pharmacology, 1 (2), pp. 58-64. DOI:10.1016/j.phanu.2013.02.001.

Harmayani, E., Kumalasari, I. D., Marsono, Y., Technology, A. and Flora, J. (2011) Effect of arrowroot ( Maranta arundinacea L .) diet on the selected bacterial population and chemical properties of caecal digesta of Sprague Dawley rats, 2 (September), pp. 278-284.

Lestari, L. A., Gama, D. B., Huriyati, E., Prameswari, A. A. and Harmayani, E. (2020) Glycemic index and glycemic load of arrowroot (Maranta arundinaceae) cookies with the addition of cinnamon (cinnamomum verum) and porang (amorphophallus oncophyllus) glucomannan, Food Research, 4 (3), pp. 866-872. DOI:10.26656/fr.2017.4(3).401.

Li, Y., Sun, Y., Zhong, M., Xie, F., Wang, H. and Li, L. (2020) Digestibility , textural and sensory characteristics of cookies made from residues of enzyme-assisted aqueous extraction of soybeans, Scientific Reports, pp. 1-8. DOI:10.1038/s41598-020-61179-9.

Maulani, R. R. and Hidayat, T. (2016) Pengembangan Pati Garut ( Maranta arundinacea L .) sebagai Pati Resisten Tipe IV, pp. 326-338.

Patel, S. (2015) Cereal bran fortified-functional foods for obesity and diabetes management: Triumphs , hurdles Seema Patel *, Journal of Functional Foods, 14, pp. 255-269. DOI:10.1016/j.jff.2015.02.010.

Sehgal, V. K., Gupta, V. K., Dash, S. K. and Swain, P. (2017) Quantitative monitoring of sucrose, reducing sugar and total sugar dynamics for phenotyping of water-deficit stress tolerance in rice through spectroscopy and chemometrics, Spectrochimica Acta Part A: Molecular and Biomolecular Spectroscopy. DOI:10.1016/j.saa.2017.10.076.

Sondak, M. R., Minantyo, H. and Winarno, P. S. (2018) Jurnal Bahan Alam Terbarukan Innovation to Pisang Barlin ( Musa Acuminata AA ) as The Substitute Flour. DOI:10.15294/jbat.v7i1.11415.

WHO (2020) Diabetes. Available from: https://www.who.int/news-room/fact-sheets/detail/diabetes [Accessed 27 May 2020]. 